\title{
The critical period effects in second language acquisition
}

\author{
Los efectos del periodo crítico en la adquisición de una segunda lengua \\ Os efeitos do período crítico na aquisição de uma segunda língua
}

\author{
Jhon Jairo Losada Rivas \\ Candidato a magister en didáctica del inglés \\ Universidad Surcolombiana \\ jhonja_1118@hotmail.com
}

\section{Resumen}

Este artículo tiene como objetivo brindar una clara revisión de algunos de los factores más importantes relacionados con la diferencia de edades y el comúnmente conocido como periodo crítico en la adquisición de una segunda lengua (SLA). Primeramente, este se centra en revisar las principales consideraciones de la Hipótesis del Periodo Crítico $(\mathrm{CPH})$ y el periodo sensible en la adquisición de otra lengua. Seguidamente, algunos aspectos influyentes son analizados tales como la edad inicial de exposición de una lengua, duración del estudio y variables actitudinales conectadas con las perspectivas anteriormente mencionadas. Finalmente, el autor concluye sugiriendo que mientras existen algunas evidencias que demostrarían ciertos efectos del periodo crítico en la adquisición de una segunda lengua, el aprendizaje de una lengua es un proceso que todos los individuos pueden emprender sin importar la edad o las etapas de maduración, ya que hay otros aspectos de carácter lingüístico, cognitivo, afectivo y sociales que también influencian el proceso de adquisición de una segunda lengua y que no están necesariamente asociados a efectos de la edad.

Palabras claves: Periodo crítico, periodo sensible, edad, adquisición de una segunda lengua.

\begin{abstract}
This article aims at providing a thorough overview of some of the most important factors in regard to age differences and the commonly known critical period in second language acquisition (SLA). Firstly, it centers on reviewing the main considerations of the Critical Period Hypothesis $(\mathrm{CPH})$ and the sensitive period in terms of language acquisition. Then,
\end{abstract}


some influential aspects in SLA are analyzed such as the age of exposure, length of study and attitudinal variables in connection with the aforementioned perspectives. In the end, the author concludes by suggesting that while there might be some evidence for certain critical period effects in second language acquisition, language learning is a process that all individuals can undertake regardless of age or maturational states, since there are other linguistic, cognitive, affective and social aspects that also influence the process of SLA and which are not necessarily associated to age-related effects.

Keywords: critical period, sensitive period, age, second language acquisition.

\section{Resumo}

Este artigo tem como objetivo apresentar um panorama claro de alguns dos fatores mais importantes relacionados com a diferença de idade e comumente conhecido como um período crítico em uma aquisição de segunda língua (SLA). Em primeiro lugar, esta revisão centra-se na principais considerações hipótese do período crítico $(\mathrm{CPH})$ e período sensível na aquisição de outro idioma. Em seguida, alguns aspectos influentes são analisados, tais como a idade da exposição inicial de um período de estudo de linguagem e comportamentais variáveis ligadas com as perspectivas acima. Finalmente, o autor conclui sugerindo que, embora exista alguma evidência de que iria demonstrar certos efeitos do período crítico para a aquisição de uma segunda língua, aprender uma língua é um processo que todos os indivíduos podem realizar independentemente da idade ou estágio de maturação, uma vez que existem outros aspectos da linguagem, cognitivo, caráter emocional e social que também influenciam o processo de aquisição de uma segunda língua e não são necessariamente associados com efeitos da idade.

Palavras-chave: período crítico, período sensível, a idade, a aquisição de uma segunda língua.

\section{Introduction}

A good number of studies have been conducted on identifying whether or not there is a critical period that influences the learning process in Second Language Acquisition (SLA henceforward). This relationship between age and success in learning a second language has been part of an ongoing debate that makes researchers still wonder about this interesting point of study: Is there an identified Critical Period for SLA? If so, what kind of factors influence such Critical Period in the acquisition of a new language? These and other questions remain unsolved, but many efforts have been made to shed light on these aspects and some results appear to be promising towards understanding this reality. In this paper, we will analyze a great variety of aspects that research studies have identified as influential regarding age and other related features in SLA. In addition to this, other perspectives in regard to this hypothesis of language learning will be analyzed with a view to giving alternative explanations to the possible effects that age plays in language acquisition.

To begin with, a general assumption has been somehow acknowledged by some people who think that the younger you learn a language, the better it is for you 
and the greater the chances are of acquiring a second language appropriately. In reference to this, Gass and Selinker (2008) supports this idea by saying that "it is commonly believed that children are better language learners than adults in the sense that young children typically can gain mastery of second language, whereas adults cannot" (p.405). The former statement represents a conception that a lot of researchers have tried to address directly aiming at finding associations among age and language acquisition.

It is then appropriate to understand one of the main hypothesis considered in the field of SLA: the Critical Period Hypothesis (CPH hereafter). According to Birdsong (1999), the $\mathrm{CPH}$ is a limited period of time when it is possible to acquire a language at nativelike levels. In line with this premise, he also pointed out that "once this window of opportunity is passed, however, the ability to learn language declines" (Birdsong, 1999, p. 1). The first person in formulating the $\mathrm{CPH}$ was Lenneberg in 1967, who noticed that acquisition from mere exposure seemed to disappear after puberty. Besides this, he also claimed that after this period of time foreign languages had to be "taught and learned through a conscious and labored effort" (as cited in Gass \& Selinker, 2008, p. 406). It is worth highlighting that this notion had been supported by previous observations made by Penfield and Roberts (1959), who had also found an apparent "agerelated point (generally after puberty) beyond which it becomes difficult or impossible to learn a second language to the same degree as NSs [native speakers] of that language" (as cited in Gass \& Selinker, 2008, p. 406).
In spite of these assertions, some other researchers established a difference between Lenneberg's $\mathrm{CPH}$ and what they regarded as a 'sensitive period' in SLA. According to Patkowski (1980):

The term "critical period" is employed here in the case of first language acquisition because it is held that absolutely no linguistic proficiency in L1 is possible past the critical point (despite possible development of non-linguistic systems of communication), while the term "sensitive period" is used in the case of second language acquisition because the limitation is on the ability to acquire complete native-like proficiency in L2. (p. 449450).

Patkowski (1980, p. 450) claims, however, that Lenneberg also connects the $\mathrm{CPH}$ with second language acquisition. According to Lenneberg (1967), a person can learn a second language after puberty, but he is careful to mention at the same time that "the incidence of language learning blocks rapidly increases" after this period (as cited in Patkowski, 1980, p. 450). From this perspective, it would seem logical to assume that there is indeed a critical period which influences the process of SLA.

Based on this and other research findings that will be discussed afterwards, different factors have been regarded as influential in the process of SLA: the age of exposure, length of study (length of stay), learning differences, motivation, social interaction, among others. What is more, certain measures have been studied with a view to establishing the real meaning of successful learning in SLA such as learning rate, type of language learning task (syntax, morphology, 
phonology) and an interesting contrast between speed of learning and ultimate attainment. The previous aspects have been estimated to account for measures of language learning and proficiency, thus leading researchers to formulate apparent relationships between a critical period and successful learning processes in SLA.

In view of this, it is worth reviewing some of the studies that have enriched this debate in SLA by also considering other elements different from the agerelated effects suggested. One must begin by looking first at some of these results to set new interpretations of the hypothesis being discussed.

\section{Age of exposure}

Firstly, when talking about age of exposure, I refer to the initial time a person is introduced and exposed to a new language. It is the beginning of the learning process that one goes through and which implies the use of different methods and styles to acquire a new system of rules that will therefore, allow the learner to use the target language effectively. Some research studies have viewed the age of exposure as the most important element to analyze when learning a second language. From this view, age is seemingly related with developmental and biological changes that allow young learners to acquire a second language at native-like levels, while older learners (generally those who start learning a second language after puberty) find it more difficult to get to such levels. Apart from this, the mastery of the language they have seems not to be as proficient as the one demonstrated by younger learners throughout their learning process.
Lightbown and Spada (2006) reviewed the age of acquisition and the critical period hypothesis in language learning and stated that "older learners may depend on more general learning abilities - the same ones they might use to learn other kinds of skills or information" (p.68) when learning a second language. They support the notion of a critical period for language learning which is believed to end around puberty. This idea that older learners may have to use other learning abilities suggests that there is a critical period which highly influences the learning process in young learners and therefore, a learning decline as a person ages would be evident.

There is also evidence from a different study that is consistent with the hypothesis of age related effects in the acquisition of a second language. Patkowski (1980) conducted a study that tested the aforementioned hypothesis by analyzing the command of syntax of learners with different age of arrival to the United States. For this analysis, sixtyseven immigrants were divided into two groups: a) A pre-puberty and, b) a postpuberty group (taking 15 years as the age of reference for this division). Subjects' syntactic ability in English was measured by trained judges who rated written transcripts of subjects' recorded interviews. Two variables were taken into consideration for the sake of the analysis. The first one had to do with the age of arrival in the US, and the second was a compound variable which regarded the length of stay along with informal (natural) and formal exposure to the language.

Based on the analysis of variance and a set of correlational analyses undertaken, results showed a strong relationship between the age of exposure to the 
language and subjects' syntactic proficiency in English. As pointed out by Patkowski (1980), "practice and instructional variables showed little or no correlation with the dependent variable. The results strongly support the hypothesis of an age related limitation on the ability to acquire full command of a second language" (p. 461). Even though the author himself admits that other sociocultural factors may also influence attitude and motivation in second language learners, he states that those factors function along with "a genetically based sensitive period" (p. 467).

Similarly, other research studies seem to support this belief that young learners are better able to acquire a second language at nativelike levels in comparison to adults and older learners. Johnson and Newport (1989) conducted a study with "46 native Chinese or Korean speakers who learned English as a second language" (p. 68). They were immersed in the target language (English) in the United States and their age of arrival ranged from 3 to 39 years old. These subjects were tested on their knowledge of English syntax and morphology and results showed that there was noticeably a linear relationship between age of exposure and performance at early ages, but surprisingly such differences in performance varied greatly with increasing age of exposure (from 16 to 39 years-old-learners).

What is interesting about these research results is that despite having an evident relationship between age and performance with subjects whose ages ranged from 3 to 15 years, that same relationship was not marked in the results obtained from subjects whose ages were between 16 and 39 years old. Consequently, they concluded that young learners were "able to achieve native fluency in the language; however, immersion even soon after that age results in a decrement in ultimate performance" (Johnson \& Newport, 1989, p. 78).

The previous study supported a maturational state in SLA and suggested a learning decline after puberty which, according to their results, started around age seven until adulthood. Nonetheless, Johnson and Newport (1989) were also careful to claim that their study showed certain differences with Lenneberg's ideas. While a learning decline was evident, a dramatic drop-off was not marked in the final results of the study. Despite the fact that these results do not exactly fit with Lenneberg's original proposal of the $\mathrm{CPH}$, it seems to show a learning decline after puberty and so, a maturational influence in SLA.

In the same way, a study that supported these results was conducted by Alene Moyer in 1999, but it focused on a different aspect of language learning: learners' performances in phonology. She carried out the study with Non-native Speakers (NNSs hereafter) of German in both, an in-country experience and classroom instruction in the target language aimed at evaluating the phonological performance of these participants. They, who were graduate students with high motivation but with no previous exposure to the language, did not get nativelike accents at the end of the study. The results suggested that "the nonnative speaker performance did not overlap with native performance" (Moyer, 1999). In addition to this, Moyer tried to explain these results by pointing out that "late learners may face neurological or motor constraints, such as entrenched articulatory habits or restricted perceptual targets for phonetic 
categories, that render the possibility of nativelike attainment highly unlikely or impossible" (as cited in Gass \& Selinker, 2008, p. 407). Based on these findings, a critical period is supported in the sense that puberty and a maturational state would be essential for young learners to master phonology in SLA and hence, nativelike fluency compared with older learners.

On the other hand, researchers have also taken a look at the flip side of the coin: adult learners and their learning rate. In a study carried out over a year with children, adolescents and adults who were learning Dutch in a naturalistic setting, Snow and Hoefnagel-Hohle (1978) found that at first, older learners (adults and adolescents) had had a faster acquisition and better performance on multiple tasks compared with younger learners (children). The study findings also suggested, however, that children (young learners) had been able to reach a similar level of proficiency and performance to the one shown by adults by the end of the study. In light of these findings, two different perspectives were presented in regard to eventual attainment and learning rate in SLA. In terms of attainment, the advantage was clear on the young learners' side. Nonetheless, when analyzing the speed of learning, the study showed completely different results and seemingly, it gave the advantage to older learners in this specific aspect.

\section{Length of study/stay}

Correspondingly, some other researchers continued being against the idea of accepting age as a predicting and constraining factor in the success in SLA. Instead, they supported a different dominant element of the process: Length of study (length of stay). This is illustrated by Hakuta, Bialystok and Wiley (2003) who noted that the age of exposure to the language could describe performance in SLA, but they argued at the same time, that there was not significant evidence that supported that idea. On the contrary, they asserted that aside from the initial age of exposure, the amount of education (length of study) could represent a distinct explanation in performance regarding second language acquisition.

This notion of length of study (length of stay) has been specially supported by researchers who believe that what makes a real difference in SLA does not depend on maturational aspects, but on the length of time that somebody spends studying (in terms of formal instruction) or acquiring (in terms of naturalistic settings) a second language. This idea led to further considerations of more aspects different from Age of Acquisition (AoA henceforth) and maturational states as the major reasons for the success in the acquisition of a new language.

According to DeKeyser and Larson-Hall (2009), "it appears that a number of factors, such as differences in input, use of L1 and L2, and a variety of socialpsychological factors may reinforce the AoA effect, but they far from fully explain it" (p. 98). In this view, they assume that there might be some critical period effects in language acquisition, and they are emphatic to highlight that age is not the only factor that affects SLA, but there are others that have an influential role in this process as well.

Finally, it is worth noting that both children and adults have great differences in language learning. While children seem to learn implicitly, adults have a diverse emphasis, and for this reason, 
explicit instruction give them an initial advantage over children. One could say that as a result of these two ways of learning, learning rate and ultimate attainment show important differences in language acquisition: adults seem to be faster learners but children are apparently better when it comes to having nativelike levels and mastery of the language.

\section{Attitudinal variables}

The learning differences mentioned above not only provide a broader perspective in regard to the critical period effects in SLA, but also shed a new light on the identification of relevant aspects that are evidently involved in the learning process. This leads us to take into consideration a different feature in the field of SLA and age differences: motivation and attitudinal variables. Motivation has generally been viewed as an essential point of departure in language learning. Once a person is motivated to do something, the intentions are centered on a specific goal and therefore, results appear to be easily obtained. The same seems to happen in language learning. When learners are motivated to accomplish a specific goal, language learning becomes a process where achievement reaches a high importance and thus, its influence cannot be discussed.

Dörnyei and Skehan (2003) defines motivation as "responsible for why people decide to do something, how long they are willing to sustain the activity, and how hard they are going to pursue it" (p. 614). Even though motivation has started to be part of this discussion since the 1990's, researchers have strongly suggested that motivation is a key element in the learning process of any individual.
Success in language learning and especially SLA, is not only a matter of reaching attainment and proficiency through the acquisition of forms and structures based upon formal instruction or exposure to the language. Instead, motivation must be viewed as a key element which contribute directly rather than indirectly in the learner's process. Following Dörnyei's assertion (1994), second language learning "is more complex than simply mastering new information and knowledge; in addition to the environmental and cognitive factors normally associated with learning it involves various personality traits and social components" (p. 274). From this perspective, the social dimension comes into play along with attitudinal variables that are part of the essential elements in L2 achievement.

Similarly, Carrió-Pastor and Mestre (2014) find it necessary to regard motivation as one of the aspects that influence successful language acquisition. While they state that motivation involves both cognitive and metacognitive aspects in each individual, they advocate that motivation is one of the many variables that "assists in the successful acquisition of a second language" (p. 244).

In consequence, when considering motivation in connection with age-related effects in SLA, children seem to have a leading advantage. They appear to be highly motivated and their attitude towards learning a language is a positive one because they are not afraid of making mistakes and being corrected by others. However, this is something that happens in a different way with adults. They often seem to feel uncomfortable with the level they have and are anxious about the mistakes they might make when using the language. As stated by Lightbown and 
Spada (2006), "adults are often embarrassed by their lack of mastery of the language and they may develop a sense of inadequacy after experiences of frustration in trying to say exactly what they mean" (p. 68).

\section{Final considerations}

Based on the already reviewed findings, it can be stated that most research studies concerning the identification of a critical period in the field of SLA have attempted to pinpoint a specific age at which learners' proficiency can be welldeveloped. In the beginning, Lenneberg (1967) formulated the CPH which gave a general concept of the main differences in learning success, taking a close look at how the acquisition of a language system was affected by age and maturation. However, if this perspective is carefully analyzed, we can find that this hypothesis centers on suggesting that after puberty, there is a dramatic learning decline in language acquisition. In fact, if such dramatic learning decline was real, research results would show a linear decay in language learning of older learners when acquiring an L2, and it seems to me that this is definitely not the case based on the aforementioned studies.

Indeed, from Lenneberg's hypothesis of the critical period, new questions appeared in SLA and other variables started to be identified in terms of age differences and learning success. Patkowski (1980) and Johnson and Newport's (1989) study gave an important support for a maturational state in SLA, although the final results of such investigations had slight differences with the original approach given by the $\mathrm{CPH}$. To cite one example, one of main the concerns regarding Johnson and Newport's study was that the findings did not give a clear explanation of the phenomenon presented. While it was evident that young learners showed a relationship between their ages and performance, the study showed that this correlation was not that marked in older learners. As a consequence, they fell short in explaining the reasons why performances were not influenced by age with this group of study.

In the same line of thought, Patkowski's study did show this same support to an age related limitation at a syntactic level. In spite of this, asserting that a maturational explanation alone accounts for the acquisition of a second language seems to me inconvenient as other factors conflate within this process. Once again, a gradual decline in performance of any kind cannot overtake the evident individual differences that both, prepubescent and postpubescent learners have.

Furthermore, Snow and HoefnagelHohle's (1978) study demonstrated very different results concerning performance, learning rate and ultimate attainment. They found that adults did better than young learners at the beginning, but after some time children had been able to reach the same level and therefore, have a similar performance. According to this, adults were faster learners, but children were better "acquirers" in the end. Certainly, one thing that could have affected these results is the fact that the study was carried out in one year, and nobody knows if more differences would have been found if a longer period of time had been devoted for this study. A new study that takes this same focus with a longer period of analysis and implementation could give more conclusive ideas in reference to these aspects. 
Aside from examining proficiency and learning rate, Moyer's (1999) study centered on revising how phonology was influenced by age in SLA. Her study was quite interesting and was different from the others, since it took a specific language skill to address the topic. One possible flaw of it is that she only carried out the study with old learners, and the chance to make a comparison between children and older learners is not given in her study. In spite of this, it provided good basis to find some of the reasons why old learners cannot avoid their foreign accents to interfere in their communicative development.

Concerning age and success in SLA, there are other authors who advocate that there are cognitive and linguistic factors which seem to have a direct effect on language acquisition regardless of age or maturational states. In regard to this, Bialystok and Hakuta (1999) claim that "correlations between age and success are spurious because the relation is actually reflecting the effects of these linguistic and cognitive factors" (p. 162). I completely agree that age should not be considered as a causal factor in language acquisition, since that would amount to neglecting the influence that other factors have on the outcomes shown in the language learning process.

\section{Conclusions}

As we can see, there are several studies that have tried to establish whether or not there is a critical period in SLA and how age can positively or negatively affect the acquisition of a new language. The debate has been centered on finding a precise explanation for learning decline and maturational states that would determine success in language learning. In my view, however, it is clear that the studies have not been totally inclusive, and in some instances, have left aside some important aspects that also influence the process of second language acquisition. Trying to explain learning success with age related effects is apparently logical. It seems to me, though, that in language learning, there are other factors that must be taken into consideration, such as motivation, learning styles, aptitudes, background knowledge, individual differences and other social variables that are quite involved and closely related with these factors. As stated by authors, like Bialystok and Hakuta, "the controversy in the debate over the status of a critical period for second language acquisition has less to do with the documentation of observations than with the interpretation of those data" (1999, p. 162).

From my point of view, and following the previous argument, age cannot be conceived as the limiting point of connection among learning success and SLA. In their book, Lightbown and Spada (2006) pointed out the following:

Age is one of the characteristics that determine the way in which an individual approaches second language learning. But the opportunities for learning (both inside and outside the classroom), the motivation to learn, and individual differences in aptitude for language learning are also important determining factors that affect both rate of learning and eventual success in learning. (p. 74).

In sum, age has been considered to influence certain aspects of the learning process such as the mastery of the language and nativelike levels of proficiency in the target language. Some evidence has suggested an apparent advantage for children to develop a better 
pronunciation and language fluency in their second language. However, further research needs to be conducted to determine the real effects of these factors in the acquisition of a new language. So far, we have identified some of those variables, but it is too early to come to a final conclusion knowing that there are still a lot of questions with unsolved answers. Finally, I strongly believe that learning a second language is a process that everybody can undertake. Regardless of age, there are always going to be differences in the learning process; differences that are natural of all individuals.

\section{References}

Bialystok, E., \& Hakuta, K. (1999). Confounded Age: Linguistic and cognitive factors in age differerences for second language acquisition. In D. Birdsong, Second language acquisition and the Critical period hypothesis (pp. 161-181).

Birdsong, D. (Ed.). (1999). Second language acquisition and the critical period hypothesis. Mahwah, NJ: Lawrence Erlbaum Associates.

Carrió-Pastor, M. L., \& Mestre, E. M. (2014). Motivation in second language acqusition. Procedia - Social and Behavioral Sciences, 116, 240-244.

DeKeyser, R., \& Larson-Hall, J. (2009). What does the critical period really mean? Handbook of Bilingualism: Psycholinguistic Approaches, 88-108.

Dörnyei, Z. (1994). Motivation and motivating in the foreign language classroom. The Modern Language Journal, 78(3), 273-284.
Dörnyei, Z., \& Skehan, P. (2003). Individual differences in second language learning. In C. J. Doughty, \& M. H. Long (Eds.), The Handbook of Second Language Acquisition (pp. 589-630). Oxford: Blackwell.

Gass, S. M., \& Selinker, L. (2008). Second language acquisition: An introductory course. New York: Routledge.

Hakuta, K., Bialystok, E., \& Wiley, E. (2003). Critical evidence: A test of the Critical-Period hypothesis for secondlanguage acquisition. Psychological Science, 14(1), 31-38.

Johnson, J. S., \& Newport, E. L. (1989). Critical period effects in second language learning: The influence of maturational state on the acquisition of English as a second language. Cognitive Psychology, 21(1), 60-99.

Lenneberg, E. H. (1967). Biological foundations of language. New York: Wiley.

Lightbown, P. M., \& Spada, N. (2006). How languages are learned (Third edition ed.). Oxford University Press.

Moyer, A. (1999). Ultimate attainment in L2 phonology. Studies in Second Language Acquisition, 21(1), 81-108.

Patkowski, M. S. (1980). The sensitive period for the acquisition of syntax in a second language. Language Learning, 30(2), 449-468.

Penfield, W., \& Roberts, L. (1959). Speech and brain mechanisms. Princeton, NJ: Princeton University Press. 
Snow, C. E., \& Hoefnagel-Hohle, M. (1978). The critical period for language acquisition: Evidence from second language learning. Child Development, 49(4), 1114-1128. 


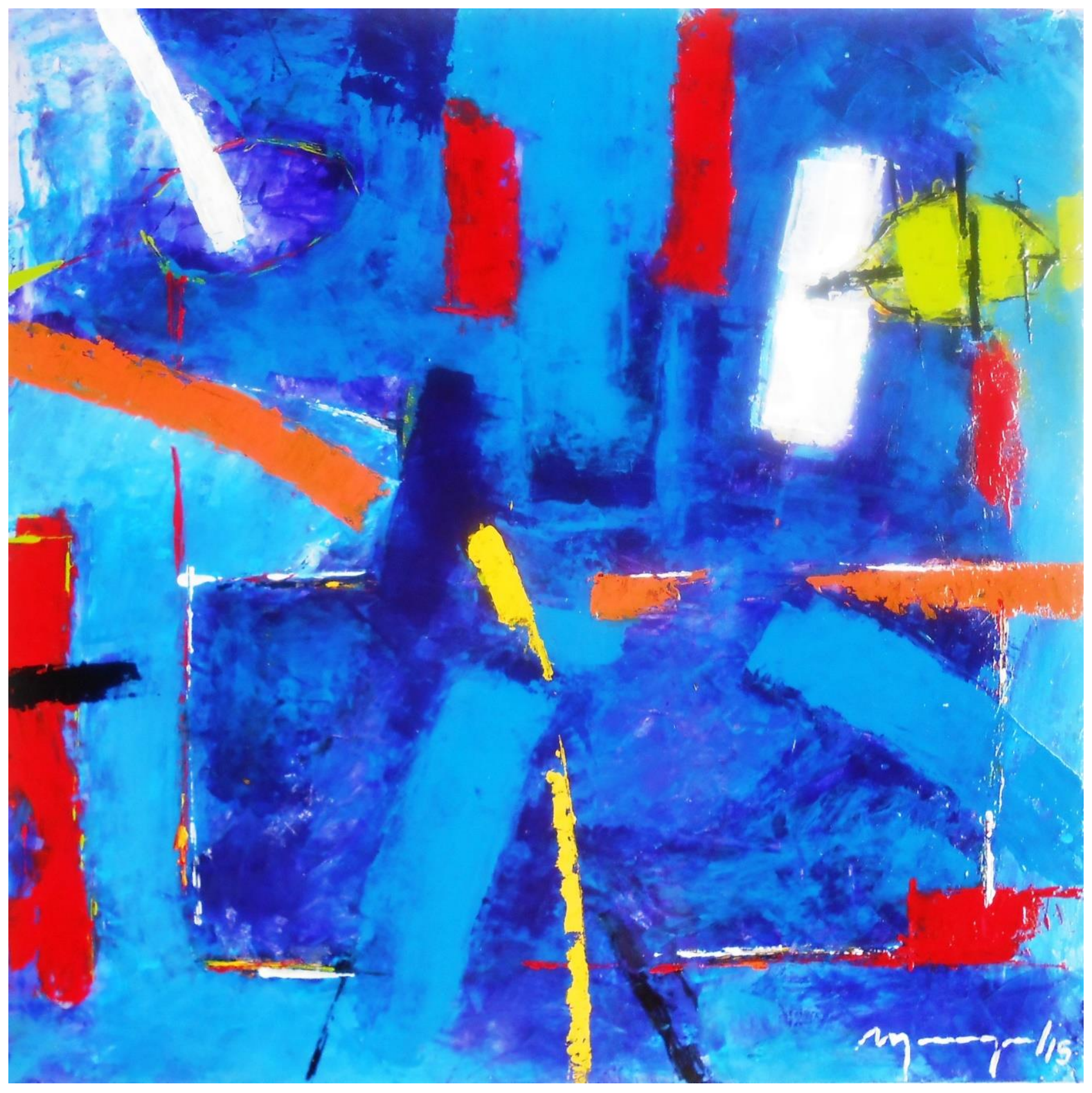

Título de la obra: espacio vital-arqueología y paisaje

Técnica: pigmentos industriales sobre polietileno

Dimensiones de la obra: $0,50 \mathrm{c} . \mathrm{ms} \times 0,50 \mathrm{c.ms}$

Año: 2014

Nombre de la imagen adjunta: 003 